\title{
位相制御レーザーパルスを用いた分子イオン化過程の量子制御 Quantum Control of Molecular lonization Process by Phase-controlled Laser Fields
}

\author{
大村 英樹
}

Hideki Ohmura

\begin{abstract}
Intense $\left(10^{12}-10^{13} \mathrm{~W} / \mathrm{cm}^{2}\right)$ phase-controlled laser fields consisting of a fundamental light and a second-harmonic light induce the directionally asymmetric tunneling ionization and the resultant orientation-selective molecular ionization. It is demonstrated that orientation-selective molecular ionization induced by phase-controlled $\omega+2 \omega$ laser fields reflects the geometric structure of the highest occupied molecular orbital. This method was robust, being free of both laser wavelength and pulse-duration constraints, and thus can be applied to a wide range of molecules.
\end{abstract}

Keywords: Quantum control, coherent control, phase-controlled laser, tunneling ionization, orientation-selective molecular ionization

\section{1.はじめに}

分子科学にとってレーザーは不可欠な役割を果たしてき た。1960 年のレーザーの発明以来, レーザー光の持つ様々 なパラメター（周波数, 強度, 時間幅, コヒーレンス etc) の可変域はこの 50 年で驚異的に拡大された。それに伴い光 を周波数で分光して, 光吸収, 発光, 光散乱などの光学応 答から, 光と物質との相互作用の特性を明らかにする分光 計測は精密かつ多様化し, 測定対象も気体, 液体, 固体, プラズマから生体まで非常に多岐にわたるようになった。 レーザーによる分子分光学は, 最も精密な物質科学の一つ として研究フロンティアを提供し続けて来た。

レーザー光利用による分子科学のもうひとつの方向性は, レーザーによる分子操作である。気体や液体の物性計測に おいて, 分子はランダムな速度, 配向で飛び回っているた め, 測定結果は速度分布や配向分布の影響を伴うことは避 けられない。分子の運動状態 (並進, 振動, 回転) や電子 状態を単一化できれば解析可能な情報量は飛躍的に増え, 高度な計測が可能となる。反応制御や物質合成についても 状況は類似しており，現行プロセスの低収率，低選択性の 原因は分子の運動状態の分布によるところが大きい。分子 の運動状態や電子状態の単一化操作は, 状態選択型のプロ セス技術を用いた機能性材料の創生にとってのキーテクノ ロジーとなる。レーザーによる分子操作は, レーザーに よって分子の量子状態量 (並進, 回転運動, 振動運動, 電 子状態）の分布を制御することに他ならない。近年, レー ザー光によって分子の量子状態や量子ダイナミクスをコ ヒーレントに制御することにより分子の運動状態，物性， 反応速度や反応経路などを制御しようとする量子制御（ま
たはコヒーレント制御）と呼ばれる研究が精力的に行われ ている ${ }^{1,2}$ 。分子の振動波束 ${ }^{3}$ や回転波束 ${ }^{4}$ の時間領域におけ る量子ダイナミクス制御や量子干渉効果の制御など様々な 要素技術が開発されている。最近では空間光変調器を用い たフイードバック制御のように広帯域のレーザー光の各ス ペクトル成分の強度や位相を精密に制御して, 分子の多数 の量子状態を同時に制御することも可能になってきた 5 。

光を照射することによって分子から電子が脱離する光イ オン化過程は, レーザーによる分子操作の観点から比較的 単純な過程の一つであり, 我々に分子のミクロな状態に関 する豊富な情報をもたらしてくれるだけでなく量子制御に 対して格好の舞台を提供してくれる。放出された光電子の エネルギー分布や放出角度分布から, 分子の電子状態や運 動状態に関する情報を得ることができる。またイオンを質 量分析することによって分子が同定できるだけでなく，そ の解離生成物は分子構造, 分子の運動状態, 化学反応過程 に関する情報を与えてくれる。最近では極限計測手法とし て, フェムト秒パルスレーザーによる時間分解光電子画像 観測によるフェムト秒領域における化学反応の実時間追跡 6 や, 光電子とイオンの多重同時計測による配向選択された 分子の光解離ダイナミクスの研究 7 などが精力的に行われて いる。

最近，我々は位相制御レーザーパルスを用いた分子イオ ン化過程の量子制御として，レーザー光の基本波と第二高 調波から構成される強い $\left(10^{12} \sim 10^{13} \mathrm{~W} / \mathrm{cm}^{2}\right)$ 位相制御 レーザーパルスによる非対称分子気体の配向を区別した配 向選択分子イオン化に成功した ${ }^{8-16}$ 。通常のレーザー光では 困難であった非対称分子の配向を区別した分子操作が位相 
制御レーザーパルスを用いることによって可能となり，分 子の配向選択の方向を相対位相差 $\phi$ によって反転できるこ とを明らかにした。あとで説明するように，分子の異方性 トンネルイオン化を通して分子の波動関数の空間領域での 選択が実現しており，この手法は光電場の非対称性という 位相制御レーザーパルスの持つ新しい光の本質に基づく空 間領域での量子制御に位置づけられる。ランダムな配向で ある気体分子の集団から特定の配向方向の分子だけを選択 イオン化する配向選択分子イオン化は, ランダム配向によ る物理情報の平均化を除去できるため重要な分子操作技術 である。

\section{2. $(\omega+2 \omega)$ 位相制御レーザー光の特徵 : 非対称光電場}

レーザー光の基本波（周波数： $\omega$ ） と第二高調波（周波 数： $2 \omega ）$ を重ね合わせて, その相対位相差 $\phi$ を精密に制御 した位相制御レーザー光 $\mathrm{E}(\mathrm{t})$ （以下 $(\omega+2 \omega)$ 位相制御レー ザー光) $\mathrm{E}(\mathrm{t})=\mathrm{E}_{1} \cos (\omega \mathrm{t})+\mathrm{E}_{2} \cos (2 \omega \mathrm{t}+\phi)$ を考える。ここで $\mathrm{E}_{1}, \mathrm{E}_{2}$ はそれぞれ基本波と第二高調波の光電場振幅である。 Figure 1(a) (b) に示されるように相対位相差 $\phi$ をゼロまたは $\pi$ に固定して重ね合わせ場合, その光電場波形は正負の振 幅が異なるために非対称な形状となる。 $(\omega+2 \omega)$ 位相制御 レーザー光は正負を区別できない通常の光電場とは異なり 静電場的な方向性が生じる。この非対称性は, 相対位相差 $\phi$ をゼロから $\pi$ に変えると反転する。このように $(\omega+2 \omega)$ 位相制御レーザー光は非対称光電場で特徵付けられ, 従来 の光とは本質的に異なる性質を示す。非対称電場の振幅は, 一周期の平均を取るとゼロとなるので, 光電場と物質との 線形な相互作用では正負の非対称性は現れない。しかし, 光電場と物質の非線形相互作用を考慮すると正負の非対称 性が現れることがあり, 高次の非線形相互作用になるほど 非対称性が顕在化する。 $(\omega+2 \omega)$ 位相制御レーザー光を用 いた様々な物理過程の制御が報告されている ${ }^{17-34}$ 。

最近, 超極短レーザーパルス発生技術の進展に伴い, パ ルス幅が伝送波周波数の 2, 3 周期程度で, パルス包絡線と 伝送波との位相差（carrier-envelope phase；CEP）が安定化 された超極短レーザーパルス（CEP 安定化レーザーパル ス）の研究が精力的に行われている ${ }^{35}$ 。Figure 1(c) (d)に示 されるようにCEP 安定化レーザーパルスも非対称光電場で 特徵づけられ，位相差をゼロから $\pi$ に変えると非対称性が 反転する。このため CEP 安定化レーザーパルスと $(\omega+2 \omega)$ 位相制御レーザー光は類似の現象を示すことがある。スぺ クトル領域でも, CEP 安定化レーザーパルスの高周波数側 のすその周波数が低周波数側のすその周波数の 2 倍以上と なると光電場の非対称性が顕在化することを示すことがで き, $(\omega+2 \omega)$ 位相制御レーザー光と状況が類似している。

このような非対称電場で特徵付けられる強い $(\omega+2 \omega)$ 位 相制御レーザーパルスを用いて, 気体分子の非共鳴イオン 化の実験を行った。 $\begin{array}{ll}\text { (a) } \phi=0 & \text { (b) } \phi=\pi\end{array}$

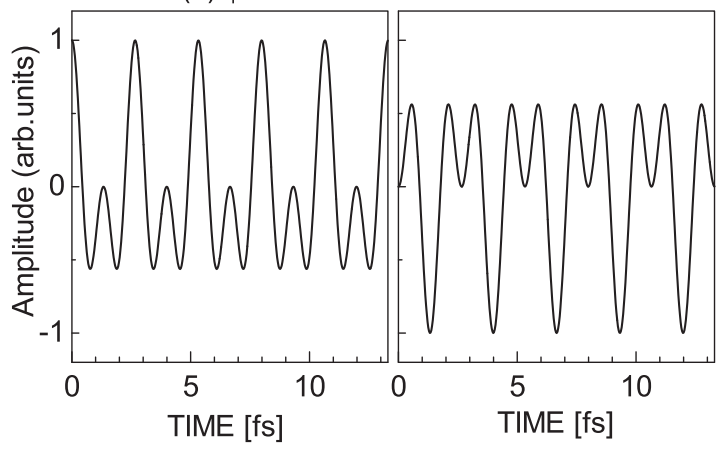

(c) $\phi=0$

(d) $\phi=\pi$

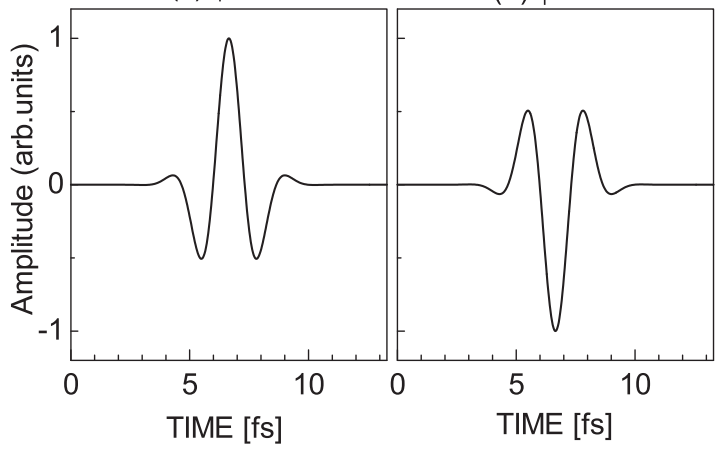

Figure 1. Wave forms of phase-controlled two-color $\omega+2 \omega$ laser fields at a relative phase difference of (a) $\phi=0$ and (b) $\phi=\pi(\mathrm{E}(\mathrm{t})=$ $\left.\mathrm{E}_{1} \cos (\omega \mathrm{t})+\mathrm{E}_{2} \cos (2 \omega \mathrm{t}+\phi), \mathrm{E}_{2} / \mathrm{E}_{1}=1.0\right)$. Wave forms of phase-stabilized few-cycle laser fields at a relative phase difference of (c) $\phi=0$ and (d) $\phi=\pi\left(\mathrm{E}(\mathrm{t})=\exp \left(-4 \log 2\left(\mathrm{t} / \mathrm{t}_{\mathrm{p}}\right)^{2}\right) \cos (\omega \mathrm{t}+\phi), \mathrm{t}_{\mathrm{p}}=2.5\right)$.

\section{3. $(\omega+2 \omega)$ 位相制御レーザーパルスによる異方性 トンネルイオン化と分子配向操作}

$(\omega+2 \omega)$ 位相制御レーザーパルスによる異方性光トンネ ルイオン化と非対称分子の配向選択効果の概念図を Figure 2 に示す。原子や分子が強いレーザー光によって励起された 場合，イオン化ポテンシャルよりも十分小さい光子エネル ギーでも非共鳴イオン化される。Keldyshの理論によると レーザー強度を I, イオン化ポテンシャルを $\mathrm{I}_{\mathrm{p}}$, レーザー波 長を $\lambda$, 光速を $\mathrm{c}$ とすると, Keldysh パラメター $\gamma=$ $2 \pi \mathrm{c} / \lambda\left(2 \mathrm{I}_{\mathrm{p}} / \mathrm{I}\right)^{1 / 2}$ によってイオン化過程は 2 つの領域に分類さ れる ${ }^{36}$ 。 $\gamma>1$ の領域では光学遷移の概念が有効であり，イ オン化過程は分子が複数の光子を吸収する多光子イオン化 によって記述できる（Figure 2(a))。レーザー強度が大きく なり $\gamma<1$ の領域になると, 光電場によって駆動される電子 や分極のような古典力学的な描像の方が物理現象を理解し やすくなる。このレーザー強度領域では原子や分子はトン ネルイオン化することが知られている。束縛電子のポテン シャルが光電場で歪むことによってその障壁が下がり, 電 子がポテンシャル障壁をトンネルすることによりイオン化 する (Figure 2(b))。トンネルイオン化は高次非線形光学 過程の典型例の一つとしてとして, 精力的に研究が行われ てきた ${ }^{37-40}$ 。最近，CEP 安定化レーザーによる光トンネル イオン化を対象とした時間領域での精密な実験が行われ, トンネルイオン化は光の 1 周期の中で光電場の最大付近の 


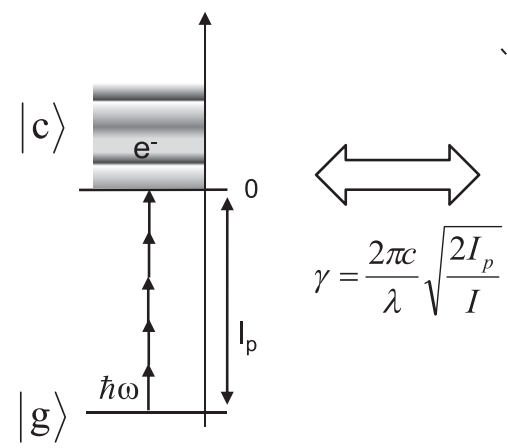

(a) multiphoton ionization $(\gamma>1)$

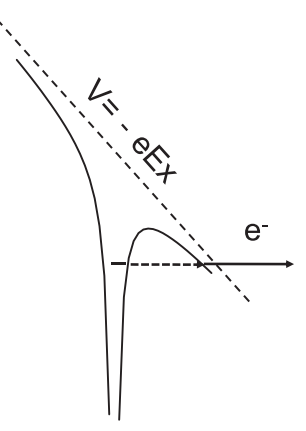

(b) tunneling ionization $(\gamma<1)$
Figure 2. Schematic diagrams of the ionization processes; (a) multiphoton ionization, (b) tunneling ionization.

アト秒領域で電子が引き抜かれていることが報告されてい る ${ }^{41}$ 。

分子のトンネルイオン化を記述する分子 AmmosovDelone-Krainov (ADK) モデルによると, 分子の最外殼軌 道（HOMO）から電子が引き抜かれイオン化が引き起こさ れるが, 波動関数の振幅がより大きい所から電子が引き抜 かれる確率が高くなる ${ }^{42,43}$ 。その結果, トンネルイオン化 確率は光電場ベクトルに対して分子配向依存性が生じる。 トンネルイオン化の分子配向依存性を反映する光解離生成 物の放出角度分布は HOMO の空間形状を反映したものにな ることが理論的に示されており 42,43 , 実験でも実際に観測 されている 44,45 。例えば， $\sigma$ 軌道の HOMO をもつ窒素分子 ではHOMO の形状を反映したダンベル型の放出角度分布が, $\pi$ 軌道の HOMO を持つ酸素分子では HOMO の空間形状を 反映したバタフライ型の放出角度分布が観測されている ${ }^{44,45}$

Figure 3(a) に示される一酸化炭素（CO）のような非対称 な HOMO を持つ分子が対称光電場をもつ単色のレーザー光 でトンネルイオン化された場合，正の配向方向の分子と負 の配向方向の分子が, 対称光電場の正負のピークでイオン 化されるため, 非対称な HOMO を反映した分子配向依存性 にはならず非対称分子の配向を区別することができない。 ところが非対称電場をもつ位相制御レーザーパルスを用い ることによって, 光トンネルイオン化に空間異方性が現れ る。 $(\omega+2 \omega)$ 位相制御レーザーパルスの非対称光電場が相 互作用すると，非対称な波動関数において振幅の大きい場 所から非対称光電場の最大の方向に異方的なトンネルイオ ン化が起こる確率が高くなる（Figure 3(a)）。その結果, Figure 3(b) に示されるようにランダム配向の気体分子集団 の中から非対称分子の配向を区別した配向選択イオン化が 起こる。

量子制御は，（i）ある特定の量子状態を選択し，（ii）熱 運動などのランダムな相互作用によってかき消される前に， 光と物質のコヒーレント相互作用を通して，選択した量子 状態をコヒーレントに時間発展させ，（iii）目標とする終状 (a)

(b)
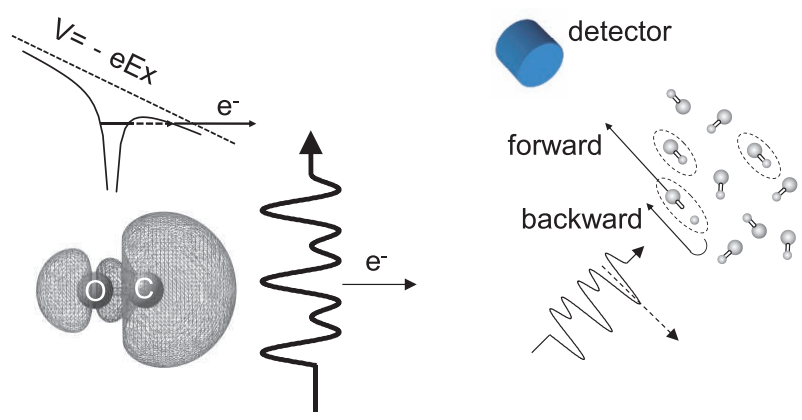

Figure 3. (a) Molecular structure and isocontour of the highest occupied molecular orbital (HOMO) of carbon monoxide (CO). (b) Schematic of the orientation-selective molecular ionization by phase-controlled $(\omega+2 \omega)$ laser field and the detection of the oriented molecular ions. We define the relative phase difference as $\phi=0$ when the electric field maxima point toward the detector (forward direction) and as $\phi=\pi$ when the electric field maxima point away from the detector (backward direction).

態に到達させ物質を制御しようというものである。このよ うな状況下では, 量子状態間で干涉効果によって観測量が 量子状態間の相対位相に依存するため, 量子状態の位相関 係を制御することが不可欠になる。具体的な例は，コヒー レントな分子振動である。レーザーによっていくつかの振 動状態が周波数領域で選択され，コヒーレントに時間発展 し干渉効果した結果, 振動波束が形成される（周波数領域 の制御と時間領域の制御はフーリエ変換でつながっている ので, 各周波数成分間の位相制御と時間領域での波形制御 は同義となる)。

気体や液体での量子制御では, 分子はランダムな配向で あり, 光と分子との相互作用の配向依存性のため均一な量 子状態の選択が困難である場合が多い。そこで量子制御を 実現するためには, 空間領域でも適切な量子状態の選択が 不可欠となる。本論文では, $(\omega+2 \omega)$ 位相制御レーザーパ ルスによる異方性トンネルイオン化によって同じ配向の HOMO が選択されており, 空間領域での波動関数の選択が 実現している。さらに単色のレーザー光では偏向方向に対 して対称に放出されていた光電子放出の方向が，基本波と 第二高調波の同時励起による干渉効果により異方性のある 光電子放出となる。

異方性光トンネルイオン化による非対称分子の配向選択 効果は，ある意味で空間領域での量子制御の結果であると 言える。

\section{4. 実験装置}

実験装置は，（1）レーザー光源，（2） $(\omega+2 \omega)$ 位相制御 レーザーパルス発生器, (3) 質量分析用真空チェンバーか ら構成される。光源は再生増幅された Ti:Sapphire レーザー (Spectra-Physics, Hurricane, 波長 ; $800 \mathrm{~nm}$, 強度 ; $1.0 \times$ $10^{14} \mathrm{~W} / \mathrm{cm}^{2}$ ，パルス幅；130 fs）を使用した。その出力を 
$(\omega+2 \omega)$ 位相制御レーザーパルス発生器に入射する。我々 は 2 つの方法で $(\omega+2 \omega)$ 位相制御レーザーパルスの発生と 制御を行った。

第一の方法はマッハーツェンダー干渉計を用いる方法で ある $(\text { Figure } 4(\mathrm{a}))^{9}$ 。光源からの出力の一部を非線形光学 結晶（BBO）で第 2 高調波に変換したあと, マッハーツェ ンダー干渉計にて $(\omega+2 \omega)$ 位相制御レーザーパルスの制御 を行う。基本波と第二高調波が分離されそれぞれ別の経路 を通る。第二高調波の経路には相対位相差 $\phi$ を制御するた めの位相板が挿入されており，位相板を回転させ入射角を 変化させることにより相対位相差 $\phi$ を精密に制御すること ができる（位相精度；0.05 $\pi$, 時間精度 ; 20 アト秒）。その 後, 基本波と第二高調波は再び重ね合わせられ，( $(\omega+2 \omega)$ 位相制御レーザーパルスとして質量分析用真空チェンバー に入射される。

第二の方法は基本波と第二高調波を同一経路に経由させ る方法である ${ }^{13}$ 。マッハーツェンダー干渉計に代表される 2 光束干渉計は, 光を 2 つに分離してそれぞれの光を位相の レベルで操作することにより高精度計測が可能となる。し

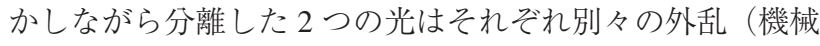
振動, 大気摇らぎ, 光学系の温度勾配など）を受けるため に外乱に敏感であり，その外乱を遮断または補正すること が必要となる。また，二つに分離した光を再び空間的に精 密に重ね合わせなければならず熟練を要する。ところが $(\omega+2 \omega)$ 位相制御レーザー光は, 2 光束の分離が空間領域 ではなく周波数領域で実現している。したがって波長の異 なる 2 光束は空間的には同一経路のまま位相制御すること

(a)

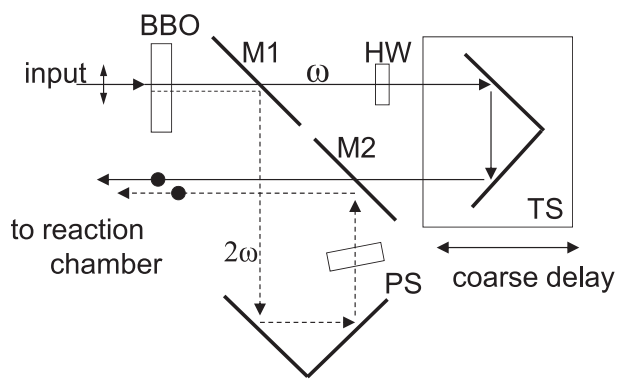

(b)

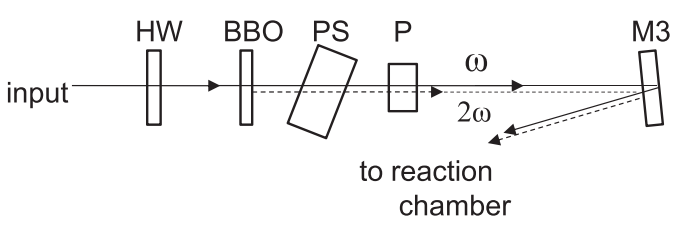

Figure 4. Schematic diagrams of the optics set generating the femtosecond phase-controlled $\omega+2 \omega$ laser fields; (a) Mach-Zehnder interferometer. (b) robust $\omega+2 \omega$ laser field generator. The elements are labeled as follows: (BBO) second-harmonic generating crystal; (M1, M2) dielectric reflectors for the $2 \omega$ beam; (HW) half-wave plate; (PS) phase shifter (quartz plate); (TS) translation stage to control the coarse delay time between the $\omega$ and $2 \omega$ pulses; (P) polarizer; (M3) dielectric mirror for propagation delay compensation. The offset between the $\omega$ (solid line) and $2 \omega$ (dotted line) beams is shown for clarity only, as the two beams overlapped completely in the experiment. The horizontal polarization is shown as an arrow, and the vertical polarization is shown as closed circles.
が可能である。その結果，それぞれの光は同じ外乱を受け ることにより外乱が相殺するため, 外乱の自己補償機能を 有した光学系を構築することが可能である。さらに 2 光束 を空間的に精密に重ね合わせる操作が省略できるため, 微 調整が不要となる。この性質を利用することにより, 微調 整の不要な外乱に非常に強い $(\omega+2 \omega)$ 位相制御レーザー光 の発生が可能となる。同一経路 $(\omega+2 \omega)$ 位相制御レーザー パルス発生器の概略図を Figure 4 (b) に示す。光源からの光 の一部を非線形光学結晶で第二高調波に変換する。基本波 とその第二高調波は同軸 2 光束となって伝搬し, まず位相 制御用光学素子 PS を通過する。位相制御用光学素子 PS は, 回転することにより入射角を変化させることの出来る合成 石英の平行平板（厚さ：10 mm）で構成される。屈折率の 角周波数依存性（分散）によって基本波と第二高調波はそ れぞれ異なる位相変化を受けるため, 相対位相差 $\phi$ を制御 することが出来る。その後, 偏光子 P（グラン・レーザー プリズム）で基本波と第二高調波の同一偏光成分だけが選 択される。フェムト秒位相制御レーザーパルスの場合, 分 散による基本波と第二高調波の時間遅延を補正する必要が あるので，時間遅延補正用ミラーM3 を経由させる。この 素子は合成石英の平行平板（厚さ：0.5 mm）の表面に第二 高調波をほぼ $100 \%$ 反射し基本波をほぼ 100\%透過する誘電 体多層膜，董面に基本波をほほ 100\%反射して第二高調波 をほほ $100 \%$ 透過する誘電体多層膜が蒸着されている。 $(\omega+2 \omega)$ 位相制御フェムト秒パルス光は時間遅延補正用ミ ラーM 3 にほぼ垂直入射し反射される。その際，基本波が第 二高調波に比べて光学素子の厚さの 2 倍だけ長い距離を伝 搬するため, 時間遅延補正用光学素子 M3 はいわゆる負分 散特性を示す。フェムト秒 $(\omega+2 \omega)$ 位相制御レーザーパル スがこの時間遅延補正用光学素子 M3 を経由することに よって，基本波と第二高調波を空間的に分離することなく 同軸性をほぼ保ったまま, 質量分析用真空チェンバーの光 学空を含むすべての光学素子で発生した分散による基本波 と第二高調波の時間遅延を補正することができる。

$\mathrm{He}$ ガスで希釈した気体試料は, 超音速分子線として質量 分析用真空チェンバーに導入され，凹面鏡で集光された位 相制御レーザーパルスが照射される。気体分子の分子配向 の観測には, 光解離反応を利用する。光強度が $10^{12} \sim 10^{13}$ $\mathrm{W} / \mathrm{cm}^{2}$ 程度に達すると, 分子は非共鳴で光イオン化した後, 分子の回転周期よりも十分短い時間で光解離反応を起こし, 解離生成物イオンを生成する。生じた光解離生成物イオン を飛行時間型質量分析装置にて検出する。通常の気体分子 はランダム配向であるので, その光解離生成物の放出方向 もランダムである。しかし特定の配向方向の分子の光解離 生成物を検出した場合, 光解離生成物の放出角度分布は, 配向方向を反映した特徵的なものとなる。Figure $3(\mathrm{~b})$ に示 されるように配向方向をイオン検出器の方向にとった場合, 光解離生成物は飛行時間（time of flight; TOF）の関数とし 
てプロットすると（TOF スペクトル）, イオン検出器に直接 向かう成分（前方放出成分； $\mathrm{I}_{\mathrm{f}}$ ）とイオン検出器から一度遠 ざかった後, 引き出し電極によってイオン検出器に導かれ る成分（後方放出成分； $\mathrm{I}_{\mathrm{b}}$ ）のピークの対として観測される。 非対称分子の配向を区別しない分子軸だけの整列の場合 (分子整列), $\mathrm{I}_{\mathrm{f}}$ と $\mathrm{I}_{\mathrm{b}}$ は等しくなるが非対称分子の配向を区 別した分子配向の場合， $\mathrm{I}_{\mathrm{f}}$ と $\mathrm{I}_{\mathrm{b}}$ が異なりピーク対は非対称 な形状となる。このピーク対の非対称性から，気体分子の 配向状態を計測することができる。

\section{5. 実験結果と考察}

\section{1 実験結果}

Figure 5 は一酸化炭素（CO）に, 強いフェムト秒位相制 御レーザーパルス（強度； $4 \times 10^{13} \mathrm{~W} / \mathrm{cm}^{2}(800 \mathrm{~nm}), 1 \times$ $\left.10^{13} \mathrm{~W} / \mathrm{cm}^{2}(400 \mathrm{~nm})\right)$, パルス幅；130 fs）を照射した時の TOF スペクトルである。一価と二価の親分子イオン $\mathrm{CO}^{+}\left(\mathrm{CO}^{2+}\right)$ と光解離生成物イオンである一価と二価の酸素 イオン $\mathrm{O}^{+}\left(\mathrm{O}^{2+}\right)$ と炭素イオン $\mathrm{C}^{+}\left(\mathrm{C}^{2+}\right)$ が観測される。光解離 生成物イオンは, Figure 3(b) で説明したよう前方放出成分 $\mathrm{I}_{\mathrm{f}}$ と後方放出成分 $\mathrm{I}_{\mathrm{b}}$ のピークの対として観測される。また 解離生成物の運動エネルギーの異なる複数の解離経路が観 測される。これらはクーロン爆発による価数の異なる解離 経路 $\mathrm{CO}^{+(\mathrm{p}+\mathrm{q})} \rightarrow \mathrm{C}^{+\mathrm{p}}+\mathrm{O}^{+\mathrm{q}}(\mathrm{p}, \mathrm{q}$ は整数) によるものである ことが報告されている ${ }^{46}$ 。相対位相差 $\phi=0$ の場合, $\mathrm{O}^{+}\left(\mathrm{O}^{2+}\right)$ では $\mathrm{I}_{\mathrm{f}}$ が, $\mathrm{C}^{+}\left(\mathrm{C}^{2+}\right)$ では $\mathrm{I}_{\mathrm{b}}$ が大きく観測される。一方, 相 対位相差 $\phi=\pi$ の場合, それぞれのイオンにおいて, $\mathrm{I}_{\mathrm{f}}$ と $\mathrm{I}_{\mathrm{b}}$ の大小関係が完全に逆転していることわかる。Figure 6 は 相対位相差 $\phi$ の関数としてプロットした光解離生成物イオ ンの前方放出成分と後方放出成分の比 $\left(\mathrm{I}_{\mathrm{f}} \mathrm{I}_{\mathrm{b}}\right)$ である。炭素 イオン $\mathrm{C}^{+}\left(\mathrm{C}^{2+}\right)$, 酸素イオン $\mathrm{O}^{+}\left(\mathrm{O}^{2+}\right)$ はとも明瞭な $2 \pi$ の振 動をしており，炭素イオンと酸素イオンはお互いに逆位相 であることが分かる。この実験結果は，非対称分子の配向 を区別して CO 分子がイオン化, 検出されており, その配 向方向が $\phi=0$ と $\phi=\pi$ で反転していることを示している。 また，一価と二価の同種イオンはお互いに同位相で振動い ることから， $\mathrm{CO}^{+}$と $\mathrm{CO}^{2+}$ は同一の配向方向でイオン化，検 出されていることがわかる。このように通常のレーザー光 では困難であった非対称分子の配向を区別した分子操作が $(\omega+2 \omega)$ 位相制御レーザーパルスによって可能であり，検 出された分子の配向方向を相対位相差 $\phi$ によって反転でき ることがわかった。また基本波の強度を $\mathrm{I}_{1}$, 第二高調波の 強度を $\mathrm{I}_{2}$ とすると, 配向分子の検出は相対強度比 $\mathrm{I}_{2} / \mathrm{I}_{1}$ に敏 感ではなく, 光電場の非対称度が最大である $\mathrm{I}_{2} / \mathrm{I}_{1}=$ $0.25\left(\mathrm{E}_{2} / \mathrm{E}_{1}=0.5\right)$ を中心に $0.09<\mathrm{I}_{2} / \mathrm{I}_{1}<1\left(0.3<\mathrm{E}_{2} / \mathrm{E}_{1}<1\right)$ にわ たる広範囲な条件で観測された。

\section{2 異方性トンネルイオン化に関する議論}

Figure 5,6より，相対位相差 $\phi$ が 0 と $\pi$ のときに検出さ

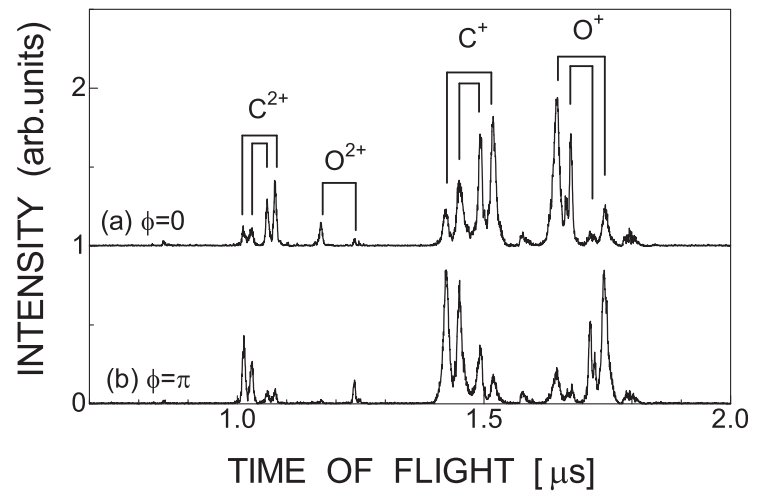

Figure 5. TOF spectra of the singly-charged and doubly-charged ions produced by dissociative ionization of $\mathrm{CO}$ molecules irradiated with phase-controlled $\omega+2 \omega$ laser fields at the relative phase difference (1) $\phi=0$ and (2) $\phi=\pi$. The solid lines indicate pairs of forward and backward peak.

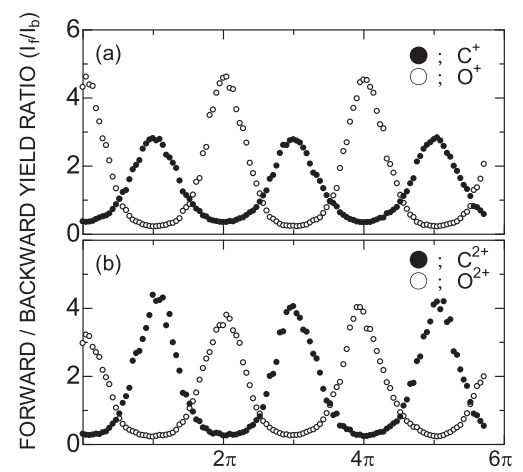

RELATIVE PHASE DIFFERENCE

Figure 6. Forward/backward yield ratio $\left(I_{1} / I_{\mathrm{f}}\right)$ of (a) singly charged and (b) doubly charged photofragment ions as a function of relative phase difference $\phi$ : (open circles) oxygen; (closed circles) carbon.

れる分子の配向方向は，異方性トンネルイオン化において 分子 ADK モデルで期待される配向方向（Figure 3(a)）と一 致していることが分かった。ここでレーザー強度の実験条 件から異方性トンネルイオン化について考察する。レー ザー強度と CO のイオン化ポテンシャルから, 多光子イオ ン化とトンネルイオン化の境界を評価する Keldysh パラメ ターは $\gamma=1.5\left(\mathrm{I}=5 \times 10^{13} \mathrm{~W} / \mathrm{cm}^{2}, \mathrm{I}_{\mathrm{p}}=14.0 \mathrm{eV}\right)$ となる。した がって，実験結果は境界領域ではあるが多光子イオン化 $(\gamma>1)$ に分類されることになり，トンネルイオン化の条件 を満たしていない。しかしながら，Kelydsh パラメターで多 光子イオン化に分類される場合でも，トンネルイオン化の 描像が有効なケースが以下に列挙するようにいくつか報告 されている。

（1）アト秒真空紫外光パルスと CEP 安定化パルスを用いた ポンププローブ型の実験による原子のトンネルイオン 化の実時間測定が行われ， $\gamma \sim 3$ でもトンネルイオン 化で説明が可能であることが報告されている ${ }^{41}$ 。

（2）ベンゼンやナフタレンなどの分子の光電子分光の実験 結果により，HOMO は分子を構成する原子にまたがっ て空間的に広がるためトンネルイオン化が起こりやす くなり，実効的に $\gamma$ は減少する。つまり多光子イオン 
化の領域 $(\gamma>1)$ でもトンネルイオン化の性質がより 顕著に現れることが指摘されている ${ }^{47}$ 。

（3）多光子イオン化は, 実験では離散的な光電子スペクト ルの観測によって判断されることが多い。しかしなが ら, 離散的なスペクトルは周期的な光電場振幅の最大 でトンネルイオン化した光電子の時間領域でのパルス 列のフーリエ変換としても説明できる。したがって, 離散的なスペクトルは多光子イオン化の証拠にはなら ず，トンネルイオン化は， $\gamma>1$ の領域ですでに始まっ ていることが理論的に指摘されている ${ }^{48}$ 。

$(\omega+2 \omega)$ 位相制御レーザーパルスによる配向選択分子イオ ン化も異方性トンネルイオン化によって直感的によく理解 できる。

\section{3 配向分子検出の他のメカニズム}

異方性光トンネルイオン化による非対称分子の配向選択 効果とは異なる配向分子検出のメカニズムとして, 気体分 子の動的分子配向（レーザー電場による断熱および非断熱 分子配向）が考えられる 49 。分子の分極と非共鳴の高強度 レーザー光による光電場との相互作用によって分子にトル クがかかり, 中性分子が光電場の最大の方向に動的に配向 するというものでる。永久双極子と $(\omega+2 \omega)$ 位相制御レー ザーパルスの非対称光電場との非線形相互作用 30,31 , また は 3 次の非線形分極と非対称電場との非線形相互作用 ${ }^{32}$ に よって, 非対称分子の配向する可能性が指摘されている。 ここで報告する実験結果にも， $(\omega+2 \omega)$ 位相制御レーザー パルスの時間幅内で分子が配向しイオン化されるという過 程が含まれる可能性がある。最近, ポンププローブ型の実 験によるフェムト秒 $(\omega+2 \omega)$ 位相制御レーザーパルスを用
いた非断熱分子配向 ${ }^{33}$ やナノ秒 $(\omega+2 \omega)$ 位相制御レーザー パルスを用いた断熱分子配向 ${ }^{34}$ が報告されているがその効 果は比較的小さく，ここで報告した実験結果への影響は小 さいと考えられる。

\section{6. その他の実験結果}

$(\omega+2 \omega)$ 位相制御レーザーパルスによる異方性トンネル イオン化と非対称分子の配向選択効果について系統的に調 べるため, Figure 7 に示される様々な分子や $(\omega+2 \omega)$ 位相 制御レーザーパルスのパルス幅を変えた実験を行った ${ }^{8-13}$ 。 ここではヨウ化へキサン $\left(\mathrm{C}_{6} \mathrm{H}_{13} \mathrm{I}\right)$ の結果について紹介す る 13 。

$\mathrm{C}_{6} \mathrm{H}_{13} \mathrm{I}$ は Figure $7(\mathrm{~b})$ に示されるように炭素を 6 個含む直 線状の分子であり，その HOMO はヨウ素原子に振幅の偏っ た非対称な形状を示す。 $\mathrm{C}_{6} \mathrm{H}_{13} \mathrm{I}$ 分子は永久双極子を持つが, この程度の大きさの分子では動的分子配向に数ピコ以上を 要するため, フェムト秒 $(\omega+2 \omega)$ 位相制御レーザーパルス の時間幅内で分子を動的配向させるのは困難であることが 予想される。一方, ある程度大きな多原子分子でも 2 原子 分子と同様に異方性トンネルイオン化によって配向選択分 子イオン化が実現できるかは, 応用上の観点から重要であ る。

Figure 8 は $\mathrm{C}_{6} \mathrm{H}_{13} \mathrm{I}$ に, 強いフェムト秒位相制御レーザー パルス（波長； $800 \mathrm{~nm}+400 \mathrm{~nm}$, 強度 ; $1.0 \times 10^{13} \mathrm{~W} / \mathrm{cm}^{2}$, パルス幅；130fs）を照射した時の TOF スペクトルである。 一価の親分子イオンと様々な光解離生成物イオンが観測さ れる。ヨウ素イオンは前方放出成分 $\left(\mathrm{I}_{\mathrm{f}}\right)$ と後方放出成分 $\left(\mathrm{I}_{\mathrm{b}}\right)$ のピークの対として観測される。その他の光解離生成 物イオンでは, 光解離時の運動エネルギーが分解能以下で (a) nonpolar molecule $\left(\mathrm{Br}\left(\mathrm{CH}_{2}\right)_{2} \mathrm{Cl}\right)$

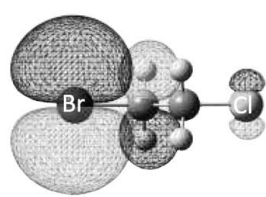

(b) large molecule $\left(\mathrm{C}_{6} \mathrm{H}_{13} \mathrm{l}\right)$

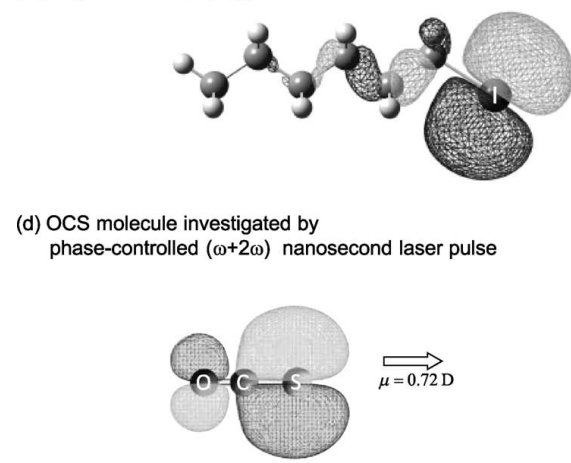

(c) systematically changing molecular system $\left(\mathrm{CH}_{3} \mathrm{X} ; \mathrm{X}=\mathrm{F}, \mathrm{Cl}, \mathrm{Br}, \mathrm{I}\right)$
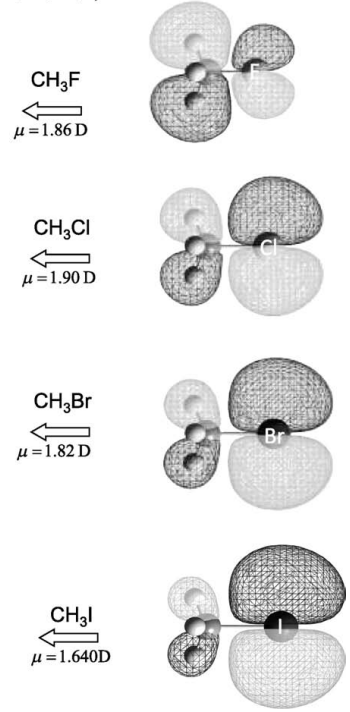

Figure 7. Molecular structures and isocontours of the highest occupied molecular orbitals (HOMOs) of investigated molecules determined by ab initio calculations using the Gaussian 03W software package. The shadings indicate the signs of the wave functions. The directions of the permanent dipoles are shown by the thick arrows. 


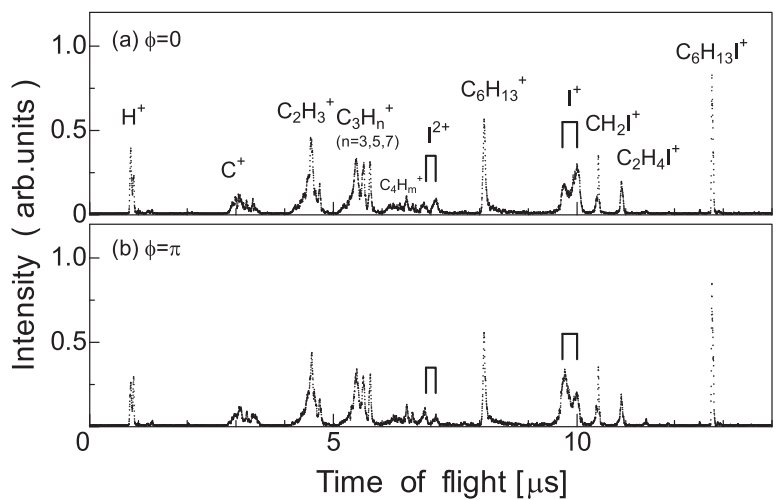

Figure 8. TOF spectra of the $\mathrm{C}_{6} \mathrm{H}_{13} \mathrm{I}^{+}$ion and its photofragments produced by irradiation of the phase-controlled $\omega+2 \omega$ laser fields at relative phase differences (a) $\phi=0$ and (b) $\phi=\pi$. The solid lines indicate the pairs of forward and backward peaks.

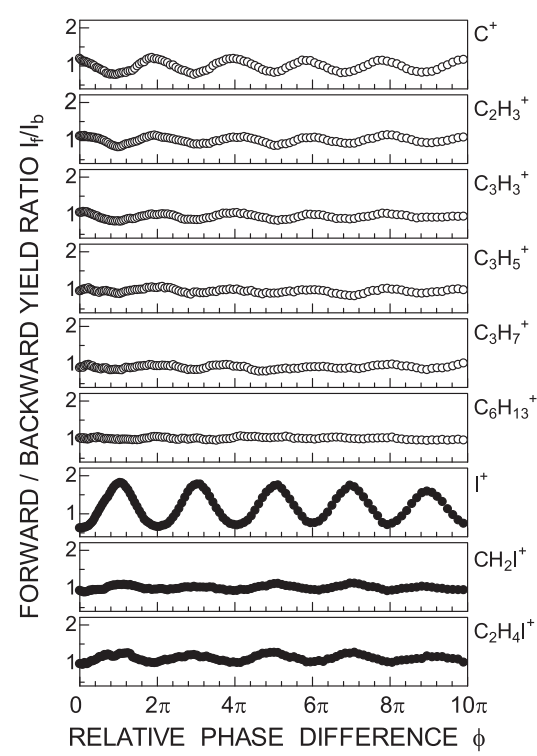

Figure 9. The forward to backward yield ratio $\left(I_{\mathrm{f}} / I_{\mathrm{b}}\right)$ of photofragment ions produced from $\mathrm{C}_{6} \mathrm{H}_{13} \mathrm{I}^{+}$as a function of $\phi$, the relative phase difference between the $\omega$ and $2 \omega$ fields: open circles, carbon and hydrocarbon cations; filled circles, iodine and iodine-containing cations.

あり，ピークの対としてではなくブロードなピークとして 観測された。相対位相差 $\phi=0$ の場合, ヨウ素イオンでは $\mathrm{I}_{\mathrm{b}}$ が大きく観測される。一方, 相対位相差 $\phi=\pi$ の場合, $\mathrm{I}_{\mathrm{f}}$ が大きく観測される。その他の光解離生成物イオンでは, 位相依存性は小さく TOF スペクトルでは判別できない。

Figure 9 は相対位相差 $\phi$ の関数としてプロットした解離 生成物イオンの前方放出成分と後方放出成分の比 $\left(\mathrm{I}_{\mathrm{f}} / \mathrm{I}_{\mathrm{b}}\right)$ で ある。 $\mathrm{C}_{6} \mathrm{H}_{13}{ }^{+}$を除くすべての光解離生成物イオンで $2 \pi$ の 振動をしており，炭素イオンおよび炭化水素カチオンとヨ ウ素イオンおよびヨウ素を含むカチオンで完全に逆位相の 関係であることが分かった。この実験結果は, 非対称分子 の配向を区別して $\mathrm{C}_{6} \mathrm{H}_{13} \mathrm{I}$ 分子がイオン化, 検出されている ことを示している。さらに検出された分子の配向方向は, 異方性卜ンネルイオン化において分子 ADK モデルで期待さ れる配向方向と一致していることがわかった。したがって, 配向分子検出のメカニズムは, 異方性トンネルイオン化に
よる非対称分子の配向選択効果であると結論される。

動的な分子配向効果では大きく重い分子ほどトルクが必 要になるため配向操作が困難になるが, 配向選択分子イオ ン化は分子の大きさ, 重さや極性の制約を受けない可能性 があり分子操作技術の観点からも興味深い結果である。

その他に, フェムト秒 $(\omega+2 \omega)$ 位相制御レーザーパルス を用いて，極性の小さい非対称分子 $\left(\mathrm{Br}\left(\mathrm{CH}_{2}\right)_{2} \mathrm{Cl}\right)$ (Figure 8 (a) )を対象とした実験を行い， $(\omega+2 \omega)$ 位相制御レーザー パルスは波動関数のレベルで極性の小さい非対称分子の配 向を識別することが可能であることを示した ${ }^{10}$ 。

また波動関数 (HOMO) の非対称性が系統的に変わる分 子系 $\left(\mathrm{CH}_{3} \mathrm{X} ; \mathrm{X}=\mathrm{F}, \mathrm{Cl}, \mathrm{Br}, \mathrm{I}\right)$ (Figure 8(c) ) を対象とした実験 を行った ${ }^{11}$ 。その結果, 検出された配向分子の向きは永久 双極子ではなく波動関数の非対称性に相関があることがわ かった。永久双極子と波動関数の非対称性が共存するよう な系でも, $(\omega+2 \omega)$ 位相制御レーザーパルスの異方性トン ネルイオン化に基づく配向選択分子イオン化が主要な効果 であることが明らかとなった。

さらに, $(\omega+2 \omega)$ 位相制御レーザーパルスのパルス幅と 波長を変えた実験として, ナノ秒 $(\omega+2 \omega)$ 位相制御レー ザーパルスを用いた実験を行った（Figure 7(d) $)^{12}$ 。ナノ秒 パルスではパルスの時間幅内で動的分子配向を起こす時間 が十分あるので動的分子配向効果の観測が期待されたが, ナノ秒パルスでも位相制御レーザーパルスの非対称光電場 と非対称波動関数との相互作用によって引き起こされる異 方性トンネルイオン化に基づく配向選択分子イオン化が主 要な効果であることがわかった ${ }^{12} 。$

\section{7. まとめ}

基本波と第二高調波を重ね合わせその相対位相を精密に 制御した強い位相制御レーザーパルスによる気体分子の配 向選択分子イオン化について述べた。この手法は分子の非 対称波動関数と $(\omega+2 \omega)$ 位相制御レーザーパルスの非対称 光電場との相互作用によって引き起こされる異方性光トン ネルイオン化に基づく空間領域での分子操作技術であるこ とが明らかとなった。その特徴は以下のとおりである。

（1）通常のレーザー光では困難であった非対称分子の配向 を区別した分子操作が位相制御レーザーパルスによっ て可能であり，分子の配向選択の方向を相対位相差 $\phi$ の符号 $(0, \pi)$ によって反転させることができる。

（2）共鳴遷移を必要としないため, 光の波長を変える必要 がなく分子の種類に依存しない。

（3）分子の極性や大きさの制約を受けない適応範囲の広い 手法となる可能性がある。

（4）分子の回転温度にそれほど敏感でなく, 回転温度の高 い分子線に対しても，高い配向選択率が実現できる。

配向選択分子イオン化は分子と六極不均一電場との相互 作用を利用した配向分子線発生法 ${ }^{50,51}$ やレーザー電場によ 
る断熱および非断熱分子配向制御 49 とはメカニズムが異な るため, これらと組み合わせれば, 3 次元的分子配向操作技 術へ展開できることが期待される。例えば, 六極不均一電 場や強いレーザー電場によって生成した配向分子線に対し て, 配向方向とは異なる方向で位相制御レーザーパルスに よる配向選択分子イオン化を行えば, 配向度の高い 3 次元 的な配向選択分子イオン化が実現できる可能性があるため, 実効的に 3 次元的な配向依存性に基づく立体効果を計測す ることのできる手法への展開が期待される。

また分子はイオン化されるとその大部分はばらばらに分 解されるが, 配向選択された分子の解離生成物の飛び散り 方は分子の立体構造を強く反映する。そこで質量分析計の 中で位相制御光による配向選択分子イオン化を行えば，質 量だけでなく分子構造の決定まで行うことのできる高機能 な質量分析装置への展開が期待される。

\section{8. 謝辞}

共同研究者である産業技術総合研究所の立矢正典, 中永 泰介, 伊藤文之, 齋藤直昭, 野中秀彦, 一村信吾の各博士 に感謝する。

この研究の一部は筆者が研究代表者として, 文部科学省 科学技術振興調整費 (若手任期付プログラム), 住友財団, 三菱財団, JSTさきがけ, (独) 日本学術振興会科学研究費 補助金（若手 A，若手 B）の支援を受けた。

\section{参考文献}

(1) Shapiro, M.; Brumer, P. Principles of the Quantum Control of Molecular Processes; John Wiley: New York, 2003.

(2) Dantus, M.; Lozovoy, V. V. Chem. Rev. 2004, 104, 1813-1859.

（3） 大森賢治, 日本物理学会誌 2004, 59, 615-618.

（4）酒井広文，日本物理学会誌 2006, 61, 263-267.

(5) Assion, A.; Baumert, T.; Bergt, M.; Brixner, T.; Kiefer, B.; Seyfried, V.; Strehle, M.; Gerber, G. Science 1998, 282, 919-922.

（6）鈴木俊法，日本物理学会誌 2003, 58, 765-769.

（7）足立純一，柳下明，日本物理学会誌 2010, 65, 416-424.

(8) Ohmura, H.; Nakanaga, T.; Tachiya, M. Phys. Rev. Lett. 2004, 92,113002 .

(9) Ohmura, H.; Nakanaga, T. J. Chem. Phys. 2004, 120, 51765180.

(10) Ohmura, H.; Saito, N.; Tachiya, M. Phys. Rev. Lett. 2006, 96, 173001.

(11) Ohmura, H.; Ito, F.; Tachiya, M. Phys. Rev. A 2006, 74, 043410.

(12) Ohmura, H.; Tachiya, M. Phys. Rev. A 2008, 77, 023408.

(13) Ohmura, H.; Saito, N.; Nonaka, H.; Ichimura, S. Phys. Rev. A 2008, 77, 053405.

（14） 大村英樹，レーザー研究 2009, 37, 16-22.

(15) 大村英樹, 光化学 2009, 40, 2-8.

(16) 大村英樹, Journal of the Vacuum Society of Japan, 2010, 53, 675-680.

(17) Kurizki, G.; Shapiro, M.; Brumer, P. Phys. Rev. B 1989, 39,
3435-3437.

(18) Yin, Y. -Y.; Chen, C.; Elliott, D. S.; Smith, A. V. Phys. Rev. Lett. 1992, 69, 2353-2356.

(19) Wang, Z.-M.; Elliott, D. S. Phys. Rev. Lett. 2001, 87, 173001.

(20) Dupont, E.; Corkum, P. B.; Liu, H. C.; Buchanan, M.; Wasilewski, Z. R. Phys. Rev. Lett. 1995, 74, 3596-3599.

(21) Hache, A.; Kostoulas, Y.; Atanasov, R.; Hughes, J. L. P.; Sipe, J. E.; van Driel, H. M. Phys. Rev. Lett. 1997, 78, 306-309.

(22) Schafer, K. J.; Kulander, K. Phys. Rev. A 1992, 45, 8026-8033.

(23) Baranova, N. B.; Reiss, H. R.; Zel'dovich, B. Y. Phys. Rev. A 1993, 48, 1497-1505.

(24) Schumacher, D. W.; Weihe, F.; Muller, H. G.; Bucksbaum, P. H. Phys. Rev. Lett. 1994, 73, 1344-1347.

(25) Charron, E.; Giusti-Suzor, A.; Mies, F. H. Phys. Rev. Lett. 1995, 75, 2815-2817.

(26) Sheehy, B.; Walker, B.; DiMauro, L. F. Phys. Rev. Lett. 1995, 74, 4799-4802.

(27) Thompson, M. R.; Thomas, M. K.; Taday, P. F.; Posthumus, J. H.; Langley, A. J.; Frasinski, L. J.; Codling, K. J. Phys. B 1997, 30, 5755-5772.

(28) Bandrauk, A. D.; Chelkowski, S. Phys. Rev. Lett. 2000, 84, 3562-3565.

(29) Ray, D.; He, F.; De, S.; Cao, W.; Mashiko, H.; Ranitovic, P.; Singh, K. P.; Znakovskaya, I.; Thumm, U.; Paulus, G. G.; Kling, M. F.; Litvinyuk, I. V.; Cocke, C. L. Phys. Rev. Lett. 2009, 103, 223201.

(30) Dion, C. M.; Bandrauk, A. D.; Atabek, O.; Keller, A.; Umeda, H.; Fujimura, Y. Chem. Phys. Lett. 1999, 302, 215-223.

(31) Guérin, S.; Yatsenko, L. P.; Jauslin, H. R.; Faucher, O.; Lavorel, B. Phys. Rev. Lett. 2002, 88, 233601.

(32) Kanai, T.; Sakai, H. J. Chem. Phys. 2001, 115, 5492-5497.

(33) De, S.; Znakovskaya, I.; Ray, D.; Anis, F.; Johnson, N. G.; Bocharova, I. A.; Magrakvelidze, M.; Esry, B. D.; Cocke, C. L.; Litvinyuk, I. V.; Kling, M. F. Phys. Rev. Lett. 2009, 103, 153002.

(34) Oda, K.; Hita, M.; Minemoto, S.; Sakai, H. Phys. Rev. Lett. 2010, 104, 213901.

(35) Krausz, F.; Ivanov, M. Rev. Mod. Phys. 2009, 81, 163-234, and references therein.

(36) Keldysh, L. V. Sov. Phys. JETP 1965, 20, 1307-1314.

(37) Faisal, F. H. M. J. Phys. B 1973, 6, L89-L92.

(38) Reiss, H. R. Phys. Rev. A 1980, 22, 1786-1813.

(39) Perelomov, A. M.; Popov, V. S.; Terent'ev, M. V. Sov. Phys. JETP 1966, 23, 924-934.

(40) Ammosov, M. V.; Delone, N. B.; Krainov, V. P. Sov. Phys. JETP 1986, 64, 1191-1194.

(41) Uiberacker, M.; Uphues, T.; Schultze, M.; Verhoef, A. J.; Yakovlev, V.; Kling, M. F.; Raushenberger, J.; Kabachnik, N. M.; Schröder, H.; Lezius, M.; Kompa, K. L.; Muller, H. -G.; Vrakking, M. J. J.; Hendel, S.; Kleineberg, U.; Heinzmann, U.; Drescher, M.; Krausz, F. Nature 2007, 446, 627-632.

(42) Tong, X. M.; Zhao, Z. X.; Lin, C. D. Phys. Rev. A 2002, 66, 033402 .

(43) Lin, C. D.; Tong, X. M. J. Photochem. Photobio. A 2006, 182, 213-219.

(44) Alnaser, A. S.; Voss, S.; Tong, X. -M.; Maharjan, M. C.; Ranitovic, 
P.; Ulrich, B.; Osipov, T.; Shan, B.; Chang, Z.; Cocke, C. L. Phys. Rev. Lett. 2004, 93, 113003.

(45) Alnaser, A. S.; Maharjan, C. M.; Tong, X. M.; Ulrich, B.; Ranitovic, P.; Shan, B.; Chang, Z.; Lin, C. D.; Cocke, C. L.; Litvinyuk, I. V. Phys. Rev. A 2005, 71, 031403.

(46) Lavancier, J.; Normand, D.; Cornaggia, C.; Morellec, J.; Liu, H. X. Phys. Rev. A 1991, 43, 1461-1469.

(47) DeWitt, M. J.; Levis, R. J. Phys. Rev. Lett. 1998, 81, 5101-5104.
(48) Reiss, H. R. Phys. Rev. A 2007, 75, 031404.

(49) Stapelfeldt, H.; Seideman, T. Rev. Mod. Phys. 2003, 75, 543557, and references therein.

(50) 大山浩, 日本物理学会誌 2007, 62, 360-364.

（51）岡田美智雄, 日本物理学会誌 2008, 63, 205-2009.

（受理日 2011 年 3 月 7 日）

\section{大村 英樹（おおむら ひでき）}

所属：(独)産業技術総合研究所 計測フロンティア研究部門

専門分野: 光物理学, 光化学, 原子分子物理, 固体物理

連絡先：= 305-8565 茨城県つくば市東 1-1-1

電子メール : hideki-ohmura@aist.go.jp

研究室 URL : http://unit.aist.go.jp/riif/ci/index.html 